\title{
Vaaran vuosien paluu
}

$\mathrm{V}$

uosi 2021 on alkanut varsin jännittävissä merkeissä maailmanpolitiikan alueella. Donald Trumpin presidenttikauden tapahtumat ennen ja jälkeen Capitolin valtauksen antavat aihetta pysähtyä miettimään populismin rajoja, jotka tällä kertaa törmäsivät länsimaisten sivistysvaltioiden viimeiseen lukkoon, oikeusvaltioperiaatteen kunnioittamiseen. Joka tapauksessa, Trumpin presidenttikauden loppuhuipennus ja sitä seurannut raaka poliittinen krapula tuntuu edelleenkin käsittämättömältä maassa, jonka pitäisi olla liberaalidemokratian kehto.

Vuonna 2017 alkanut Trumpin kausi Yhdysvaltain presidenttinä oli alusta alkaen täynnä globaaleja jännitteitä. Trumpin vaalivoitto tuli monille amerikkalaisille yllätyksenä. Vielä enemmän se tuli yllätyksenä kansainväliselle yhteisölle, joka myöhemmin sai totutella Trumpin uudenlaiseen otteeseen tehdä maailmanpolitiikkaa. Trump irrotti Yhdysvallat Pariisin ilmastosopimuksesta, Iranin ydinsopimuksesta ja WHO:n jäsenyydestä. Yhtenä keskeisenä saavutuksena kuitenkin voidaan pitää sitä, että Trumpin kaudella Yhdysvallat ei aloittanut ainoatakaan aseellista sotaa, vaikka sotilaallisia jännitteitä Iranin Pohjois-Korean kanssa Yhdysvalloilla olikin. Sen sijaan lukuisia kauppasotia Trump aloitti, ja niiden vaikutusten kanssa maailma elää vielä Trumpin kauden jälkeenkin.

Kotimaassaan Trumpin populistinen uho vaihtui marraskuun vaalituloksen selviämisen jälkeen epätoivoiseksi yritykseksi voittaa vaalit keinolla millä hyvänsä. Trumpin lakimiesarmeijan esittämille vaalivilppiepäilyille ei löytynyt vaa’ankieliosavaltioiden oikeusasteissa kestävää näyttöä. Sekään ei Trumpia pysäyttänyt, vaan viimeisenä, ja hänelle kohtalokkaaksi osoittautuneena yrityksenä oli usuttaa väkijoukot Capitolille keskeyttämään vaalituloksen vahvistamista. Capitolin valtaus kuitenkin epäonnistui pahimmalla tavalla siinä, mihin se pyrki. Koko maailma seurasi reaaliaikaisesti, kuinka Trumpin moninainen ja varsin värikkääksi osoittautunut kannattajakunta häpäisi Yhdysvaltain demokratian kaikkein pyhimmän vulgaarilla tavalla. Tämä oli liikaa myös useimmille republikaaneille, jotka olivat katselleet sormiensa läpi tilanteen eskaloitumista useiden viikkojen ajan. Lopulta kansalliskaartin ja liittovaltion joukkojen saapuessa Yhdysvallat valtasi ikään kuin valtasi sotilaallisesti itsensä, ja palautti järjestyksen jotta demokratia voisi toteutua. Symboliikan kannalta oli erittäin tärkeää, että vaalitulos palattiin sinetöimään vielä samana iltana vandalisoidulle Capitolille.

Capitolin tapahtumat sinetöivät Trumpin kohtalon henkilönä. Hänen loppukautensa kului pakotetussa hiljaisuudessa. Hänen poistumisensa valkoisesta talosta oli yksinäinen ja karu. Trumpin mahtipontinen ja omintakeinen valtiomiesura koki suurimman mahdollisen nöyryytyksen. Hänet muistetaan häviäjänä, joka viimeisenä merkittävänä presidentillisenä tekonaan yritti vallan anastamista itselleen. 
Trump henkilönä on poliittinen ruumis, mutta hänen edustamansa populismi ei ole kuollut, ei Yhdysvalloissa, eikä muualla maailmassa. Politiikka on polarisoitunut lähes kaikkialla länsimaissa viimeisen kymmenen vuoden aikana. Ääripäät ruokkivat toistensa kasvua, vihan ja koston heiluriliikkeen liikerata laajenee. Maailma elää nyt epävakaita aikoja, jossa mikä tahansa uskomattomalta tai epätodelliselta tuntuva asia tai ilmiö onkin yllättäen todellisuutta. Poliittinen keskitie, kompromissit, vastaantulo, vastavuoroisuus, yhteinen näkemys ja luottamus ovat käyneet harvinaiseksi. Yhdysvalloissa Bidenilla on lähes ylivoimainen työ vereslihalle revenneen kansan yhdistämisessä. Omat haasteensa on myös post-Brexit Euroopassa, jossa nationalismi nostaa vaarallisella tavalla päätään, Venäjän tilanne on epävakaa, ja Euroopan unioni monenlaisissa vaikeuksissa.

Elämme vaarallisia aikoja, taas kerran.

Saimme joulukuussa 2020 suru-uutisen Markku Temmeksen poismenosta. Tässä lehdessä julkaistaan muistokirjoitus, jonka ovat laatinen Markun kollegat ja ystävät. Markku oli yksi suurista vaikuttajista suomalaisen julkishallinnon kehittämisessä ja tutkimisessa, jäämme kaipaamaan hänen syvällistä osaamistaan ja valoisaa persoonaansa.

Jussi Kivistö, päätoimittaja 